Relations industrielles

Industrial Relations

\title{
EPOC Research Group, New Forms of Work Organization - Can Europe Realise its Potential?
}

\section{John Godard}

Volume 54, numéro 1, 1999

Relations industrielles et nouveaux systèmes productifs

Industrial Relations in the New Workplace

URI : https://id.erudit.org/iderudit/051228ar

DOI : https://doi.org/10.7202/051228ar

Aller au sommaire du numéro

Éditeur(s)

Département des relations industrielles de l'Université Laval

ISSN

0034-379X (imprimé)

1703-8138 (numérique)

Découvrir la revue

Citer ce compte rendu

Godard, J. (1999). Compte rendu de [EPOC Research Group, New Forms of Work Organization - Can Europe Realise its Potential?]. Relations industrielles /

Industrial Relations, 54(1), 203-205. https://doi.org/10.7202/051228ar

Tous droits réservés (C) Département des relations industrielles de l'Université Laval, 1999
Ce document est protégé par la loi sur le droit d'auteur. L'utilisation des services d'Érudit (y compris la reproduction) est assujettie à sa politique d'utilisation que vous pouvez consulter en ligne.

https://apropos.erudit.org/fr/usagers/politique-dutilisation/ 
notamment tributaire de la division théorique actuelle de l'étude du monde du travail. Le risque que la recherche en relations industrielles perde de sa spécificité existe, mais les auteurs y voient une occasion d'utiliser ces apports pour renforcer les théories et les bases conceptuelles propres au monde du travail et à ses régulations. Cet ouvrage s'avère le premier du genre et constitue un outil sérieux, fort bien documenté et particulièrement réussi à montrer la cohérence et les défis qui s'annoncent dans l'étude des faits dans le monde du travail, tel que cerné en relations industrielles.

SYLVIE MONTREUIL. Université Laval

New Forms of Work Organization - Can Europe Realise its Potential? by EPOC RESEARCH GROUP, Dublin: The European Foundation for the Improvement of Living and Working Conditions, 1997, ISBN 92-828-1888-8.

As in North America, there has been considerable interest within the European Union (EU) in the diffusion and effects of various workplace "innovations," with many convinced that these innovations benefit both employees and employers and that they offer the potential for a transformation to a new, "social partnership" model of work organization and employment relations. These innovations involve "direct" rather than more traditional, representational forms of participation, either through the reorganization of work so that extended rights and responsibilities are granted to employees (e.g., autonomous groups), or through increased consultation with employees (e.g., suggestion schemes, quality circles).

This book represents an interim report on a 1996 survey of employers in ten EU countries as to nature and extent of both delegative and consultative forms of direct participation, the motives underlying their implementation, their links with organizational strategies, their effects on employers and employees, how they are implemented and managed, and what their relationships are with employee qualifications, training, and remuneration systems. The survey involved a questionnaire consisting of (by my count) well over 200 items, and mailed to the general manager in 33,427 workplaces across the ten countries. It was sponsored by the European Foundation for the Improvement of Living and Working Conditions, an EU funded research institute located in Dublin, and was conducted by an eleven member research team, coordinated by Keith Sisson of Warwick.

In smaller countries (Ireland, Portugal, Denmark, the Netherlands, Sweden) workplaces with less than 20 employees were excluded, while in larger countries (France, Germany, Italy, Spain, the U.K.), the cut-off was 50 employees. The questions were targeted at the largest occupational group in each workplace, and the sampling was random, including both public and private sector workplaces. Though it varied considerably by country (from 9.8 percent in Spain, to 38.8 percent in Ireland), the overall response rate was 17.8 percent, yielding a final sample of 5,786 workplaces. The data were weighted on the basis of sector, workplace size, and national labour force size in order to eliminate sample distortions.

The main findings as to the extent and intensity of direct participation are largely consistent with those from similar surveys in Canada and the U.S. Though more than four out of five of those workplaces participating in the survey had some form of direct participation, only about one in seven had adopted more than a few forms, and the scope of participation was typically limited; the authors calculate that only about two percent appear to have undergone a 
"transformation" along the lines of a sociotechnical systems or "Scandanavian" approach. The authors also observe considerable variation across the ten countries, finding that there is no clearly identifiable "Northern" European pattern, but that there does appear to be a "Southern" European one, embracing Italy, Portugal, and Spain. Direct participation is less pervasive in these countries.

The primary motivation reported for the adoption of direct participation schemes was economic, though improving the quality of working life was also cited as an important secondary motivation. Respondents perceived each of the forms adopted as having positive effects on various economic and behavioral outcomes, especially where one form was practised intensely rather than a number of forms to a limited extent. Of note, consultative participation schemes were considered to be as effective as more delegative forms, including the use of work groups, even though the latter have received the greatest attention in the managerial and policy literature. Also of note, the introduction of direct participation entailed workforce reductions in between twenty and forty percent (depending on the form of participation) of participating workplaces, though there was a higher likelihood of subsequent employment growth in workplaces introducing a direct participation scheme than in those not doing so. The survey did not address the magnitudes of these reductions or of subsequent growth.

Employee qualifications and training, including social skills needed for group work as well as vocational training, were found to be important to the perceived effectiveness of direct participation schemes, as was participation by employees or their representatives in the implementation and regulation of these schemes and the provision of bonuses for either group performance or flexibility. However, around half of the workplaces in this study offered no training in social skills, and around a quarter offered no employee involvement in the implementation and regulation processes.

In addressing why direct participation is not more fully adopted, the authors speculate that part of the problem may be that it is relatively new to most organizations and difficult to implement, so that it is still in the process of diffusion within and across workplaces. Though their data provide some support for this, the authors seem to prefer a less optimistic interpretation: that the costs associated with direct participation can be high, and the benefits may be sufficient to warrant these costs in only a limited number of workplaces.

The authors' conclusions about the prospects for "social partnership" through direct representation are also not optimistic. The finding that direct participation is often associated with job loss leads the authors to conclude that it cannot be presented as something from which everyone gains. They also conclude that, to maximize the effects of direct participation, policy makers will have to take measures to address the "representation" gap that exists in many workplaces. Finally, they observe that, while a few countries (the Netherlands and Sweden) are characterized by a wider institutional and social context conducive to direct participation, many others are not. In the latter, employers are unlikely to be persuaded of the need to adopt direct participation with the scope or the intensity envisioned by proponents.

This report is only a preliminary one, and the associations reported are based on tabular breakdowns rather than multivariate analysis. The data also suffer from a number of problems common to workplace mail surveys and which may be especially serious for descriptive findings. In particular, many of the data are perceptual, including measures of the effectiveness of reforms. Moreover, the low overall response rate renders the generalizability of the results somewhat suspect, despite attempts by the authors 
to demonstrate that their sample is representative. This may be especially so given the design of the present survey, which was billed to potential respondents as "a survey into the role of direct participation in organizational change" which "will take less than 30 minutes." My experience is that employers without direct participation schemes or for whom such schemes have proven ineffective may be less likely to invest the time needed to respond to a survey of this length, believing the survey not to be applicable to their workplace or relevant to their interests.

As is often the case with survey data, the data also do not always speak for themselves. Rather, much depends on how they are analyzed and interpreted. While the results are clearly presented and well-argued, the conclusions drawn by the authors may go somewhat beyond what the data show. For example, the finding that direct participation schemes are often associated with layoffs may say less about these schemes than about the economic conditions and institutional context under which they are often implemented. It does not suggest an inherent association.
In view of these limitations, both the results and conclusions should be interpreted with some caution. Yet the authors' findings seem to reinforce what is now becoming a common theme in the literature: that the adoption of workplace innovations is not inherently consistent with the interests of either employers or employees. Rather, much may depend not only on the workplace context, but also on the wider institutional and social context. Thus, the optimistic view that direct participation represents a "voluntaristic" alternative to state involvement in labour markets, one which enhances both equity and efficiency if only employers can be convinced to take it seriously and various barriers are removed, may not be justified. Rather, there may be need of more basic institutional reforms. Ideally such reforms would induce employers to adopt the "high skill, high pay" work arrangements which many have associated with direct participation. But if not, they should at minimum seek a better balance between equity and efficiency considerations than is presently characteristic of many western nations.

JOHN GODARD

University of Manitoba

\section{The Management of Labour: A History of Australian Employers}

by Christopher WRIGHT, Melbourne: Oxford University Press, 1995, 314 p., ISBN 0-19-553549-9.

It is a privilege to review such an insightful and timely contribution to contemporary debates concerning the nature of employer strategy. Chris Wright's The Management of Labour: A History of Australian Employers should be perceived as an important text, not simply as an elegant historical account of Australian employers, but for the challenge it represents to traditional orthodoxy. The book offers a forceful and cogent argument against the widely held view that employers 'muddle through' the management of industrial relations in reactive and uncer- tain fashion. According to Wright, not only does the historical evidence of Australian employers lend support to the notion of strategic choice but that such strategic choices made within the context of specialized employee management practices are nothing new.

As Wright argues, in general, the overwhelming focus of industrial relations discourse over the last decade on innovation in the management of human resources and industrial relations has occurred without reference to historical developments. Contemporary literature concerning 'soft' 